\title{
Population dynamics of bacteria associated with different strains of the pine wood nematode Bursaphelenchus xylophilus after inoculation in maritime pine (Pinus pinaster)
}

\author{
Mariana Roriz, Carla Santos, Marta W. Vasconcelos* \\ CBQF-Escola Superior de Biotecnologia, Universidade Católica Portuguesa, Rua Dr. António Bernardino de Almeida, 4200-072 Porto, Portugal
}

Keywords:

Bacteria

Bursaphelenchus xylophilus

Nematode

Pine wilt disease

Pinus pinaster

Symptoms

\begin{abstract}
A B S T R A C T
For a long time it was thought that Bursaphelenchus xylophilus was the only agent of the pine wilt disease. Recently, it was discovered that there are bacteria associated with the nematodes that contribute to the pathogenesis of this disease, mainly through the release of toxins that promote the death of the pines. Among the species most commonly found, are bacteria belonging to the Bacillus, Pantoea, Pseudomonas and Xanthomonas genera.

The main objective of this work was to study the effect of inoculation of maritime pine (Pinus pinaster) with four different nematode isolates, in the bacterial population of nematodes and trees, at different stages of disease progression. The monitoring of progression of disease symptoms was also recorded. Also, the identification of bacteria isolated from the xylem of trees and the surface of nematodes was performed by classical identification methods, by the API20E identification system and by sequencing of bacterial DNA.

The results showed that for the symptoms progression, the most striking difference was observed for the pines inoculated with the avirulent isolate, C14-5, which led to a slower and less severe aggravation of symptoms than in pines inoculated with the virulent isolates. In general, it was found that bacterial population, inside the tree, increased with disease progression. A superior bacterial quantity was isolated from pines inoculated with the nematode isolates HF and 20, and, comparatively, few bacteria were isolated from pines inoculated with the avirulent isolate. The identification system API20E was insufficient in the identification of bacterial species; Enterobacter cloacae species was identified in $79 \%$ of the isolated bacterial colonies and seven of these colonies could not be identified by this method. Molecular identification methods, through bacterial DNA sequencing, allowed a more reliable identification: eleven different bacterial species within the Bacillus, Citrobacter, Enterobacter, Escherichia, Klebsiella, Paenibacillus, Bacillus, Citrobacter, Enterobacter, Escherichia, Klebsiella, Paenibacillus, Pantoea and Terribacillus genera were identified. General bacterial diversity increased with the progression of the disease. Bacillus spp. were predominant at the earlier stage of disease progression and Klebsiella oxytoca at the later stages. Furthermore, bacterial species isolated from the surface of nematodes were similar to those isolated from the xylem of pines.

In the present work new bacterial species were identified which have never been reported before in this type of study and may be associated with their geographical origin (Portugal). P. pinaster, the pine species used in this study, was different from those commonly grown in Japan and China. Furthermore, it was the first time that bacteria were isolated and identified from an avirulent pine wood nematode isolate.
\end{abstract}

\section{Introduction}

1.1. Pine wilt disease, Bursaphelenchus xylophilus, Monochamus galloprovincialis and Pinus pinaster

The pine wilt disease (PWD), as its name implies, is a disease found in pine species (Pinus spp.) whose main and best known

\footnotetext{
* Corresponding author. Fax: +351 225090351. E-mail address: mwvasconcelos@esb.ucp.pt (M.W. Vasconcelos).
} 
etiologic agent is Bursaphelenchus xylophilus (Steiner \& Buhrer) Nickle, the pine wood nematode (PWN).

In Portugal, the vector of $\mathrm{PWN}$ is Monochamus galloprovincialis Olivier 1795 (Sousa et al., 2001, 2002), as the nematode is transported in the body of the insect (Aikawa, 2008; Jones et al., 2008).

Once infected, trees can die in less than a year, if environmental conditions are favorable (Yoshimura et al., 1999; Jones et al., 2008). One of the earliest symptoms of infection is the reduction or cessation of resin's exudation on tree trunks, followed by the discoloration of pine needles and death of the tree (Jones et al., 2008).

The maritime pine, $P$. pinaster, is the most popular host as the insect vector feeds from it during its maturation that causes the transmission of PWN to host trees (Mota and Vieira, 2008b). Stone pine, Pinus pinea, is one of the species considered "resistant" or less susceptible to the disease, not being consumed or colonized by the vector $M$. galloprovincialis. $P$. pinaster trees play an important role in pine production, in the wood and resin industry, as well as coastal protection, being distributed throughout most of the country (Mota and Vieira, 2008a).

\subsection{The role of bacteria in the infection mechanism}

The pathogenic mechanism of PWD has not been well elucidated. For several years it was thought that the PWN was the only etiologic agent of the disease (Mamiya, 1983; Nickle et al., 1981; Nobuchi et al., 1984; Myers, 1988; Fukuda et al., 1992; Yang, 2002). More recent approaches report the existence of bacteria in symbiosis with nematodes that somehow have a crucial role in the pathogenesis of the disease; however, this hypothesis is still controversial (Oku et al., 1979; Tamura, 1983; Kawazu et al., 1996b; Cao, 1997; Kawazu and Kaneko, 1997; Kawazu, 1998; Han et al., 2003; Zhao et al., 2003, 2005; Xie and Zhao, 2008).

Among the main species of bacteria that are associated with PWN are the genus Pantoea, Pseudomonas and Xanthomonas (Higgins et al., 1999; Han et al., 2003). It was also found that bacteria in different geographic zones may differ (Han et al., 2003; Zhao et al., 2003; Wang et al., 2010). The main species found in China belong to the genus Pseudomonas, in Japan to the genus Bacillus and in Korea both are present (Zhao, 2008). Xie and Zhao (2008) concluded that at later stages of the disease, when the number of nematodes increases rapidly, the bacteria population increases in volume and variety of species.

It is also known that trees infected with bacteria alone or only with aseptic nematodes did not develop the disease, but the combination of nematodes and bacteria leads to the manifestation of the disease symptoms (Oku et al., 1980; Zhao et al., 2000, 2003; Han et al., 2003).

Thus, the PWD is a complex process that involves the PWN and the phytotoxin-producing bacteria associated with it (Zhao et al., 2003; Xie and Zhao, 2008; Kwon et al., 2010; Wang et al., 2010) whereas bacteria alone are not capable of causing disease (Zhao et al., 2003; Jones et al., 2008). However, some think that because bacteria exist inside and outside of the tree, they are contaminants and are not pathogenic (Yang, 2002). All the different experimental data indicate that there is no consensus about the actual role of bacteria in disease progression.

As little is known regarding the bacterial population in Portuguese nematode isolates and the bacteria associated with the Japanese avirulent isolate C14-5, and how it compares to virulent isolates, this work is intended to study the effect of inoculation of healthy $P$. pinaster trees, with four different nematode isolates (HF, 20, 8A and C14-5), in the bacterial population of either the nematode or the tree itself, at different stages of disease progression ( $3 \mathrm{~h}, 7$ days and 14 days after inoculation). It also aims at identifying the bacterial species isolated from the xylem of the trees and from the surface of the nematodes.

\section{Materials and methods}

\subsection{Source and culture of nematodes}

Three virulent isolates of B. xylophilus (HF and 20, geographical isolates from Setúbal region and 8A from Portuguese central region), and an avirulent isolate (C14-5, from Japan), were used in the experiments.

All B. xylophilus cultures were grown on barley seeds with Botrytis cinerea Pers. mycelium at $26^{\circ} \mathrm{C}$, in the dark, for 7 days. Juveniles and adult nematodes were extracted using the Baermann funnel technique (van Bezooijen, 2006) during $24 \mathrm{~h}$ at $25^{\circ} \mathrm{C}$.

The total number of nematodes was determined as follows: $20 \mu \mathrm{l}$ of the nematode suspension obtained from the Baermann funnel were placed in a nematode counting dish and living nematodes were counted and estimated for the initial solution. The solution was then adjusted to a final concentration of approximately 2000 nematodes $/ \mathrm{ml}$ sterile deionized water and used in the inoculation experiments.

\subsection{Source, culture and inoculation of pines}

The experiments were carried out on 1-year-old Portuguese maritime pine specie $P$. pinaster at $\mathrm{CBQF}$ - Escola Superior de Biotecnologia da Universidade Católica Portuguesa. Pines were provided by Sociedade Agrícola Pecuária Melo \& Cancela Lda. and kept in a plant growth chamber (Fitoclima S600, Aralab Portugal) scheduled for $80 \%$ humidity, photoperiod of $8 \mathrm{~h}$ light and $16 \mathrm{~h}$ darkness and temperatures of 26 and $24^{\circ} \mathrm{C}$ for periods of dark and light, respectively.

Nematodes were inoculated in pines according to the Futai (1980) method. One hundred and forty-four pines were inoculated with the different PWN isolates and 27 others without treatment (non-inoculated) were used as controls (Ø).

Three experimental points were considered: an early response of $3 \mathrm{~h}$ (3hai), a mid response of 7 days (7dai) and a later response of 14 days after inoculation (14dai).

\subsection{Development of symptoms by the diseased pines}

One of the earliest symptoms of pine wilt disease is the cessation of resin exudation. For this reason, in order to confirm disease progression, resin exudation was monitored. After every experimental point, a $5 \mathrm{~mm}$ hole in the trunk was made using a sterile blade for each of the inoculated and control pines to monitor the resin flow. Also, a visual scale of symptoms that consists of four levels of disease progression was used, ranging from healthy to dead plant according to Zhao et al. (2008).

\subsection{Determination of the presence of nematodes at different experimental time points}

In all experimental time points, the whole pine stem was cut into small pieces and PWN were extracted with the Baermann funnel technique to check if the inoculation process was effective and if the nematodes had survived.

\subsection{Calculating the quantity of inoculated chips with bacterial colonies}

The quantity of inoculated chips with bacterial colonies was determined according to Xie and Zhao (2008): a $20 \mathrm{~cm}$ long, 1 -year-old inoculated stem was sterilized with $75 \%$ ethanol and 
both ends were cut; the central wood was then cut into $2 \times 2 \times 5 \mathrm{~mm}$ pieces $(W \times D \times H)$. Eight pieces of the stem of a sample from inoculated and control pines were placed into a Petri dish containing nutrient agar (NA) medium (Frilabo, Portugal) and incubated at $26^{\circ} \mathrm{C}$ for 3 days. Bacteria that appeared in the site around the chips and by the nematode movement were placed in NA. These bacteria were also selected for identification (as described later).

Five stem samples were collected from the different experimental points and five replicate dishes, for each sample, were used to calculate the amount of bacterial colonies on the inoculated chips over all the chips from a treatment.

\subsection{Isolation of bacteria from the surface of nematodes}

Bacteria were also isolated from the surface of the four nematode isolates as described by Han et al. (2003): the solution of PWN obtained from the Baermann funnel was centrifuged at $17 \mathrm{~g}$ for $6 \mathrm{~min}$ and the supernatant was discarded; the remaining PWN were disinfected with $3 \% \mathrm{H}_{2} \mathrm{O}_{2}$ for 5 min; finally, a single nematode was removed with a thin metal needle and placed on a plate with NA media which was incubated at $26^{\circ} \mathrm{C}$. Bacterial colonies which appeared in the track left by the nematodes were successively transferred to NA for colony purification.

\subsection{Identification of bacteria by classical methods}

Both isolated bacterial colonies from xylem and the surface of nematodes were selected for identification based on macroscopic differences. Morphologic characteristics (size, color, shape, transparency, prominence, edge and viscosity) of the purified isolated bacteria from the trees and nematodes were registered. Each isolate was tested for Gram stain: the smear was first stained with crystal violet for $30 \mathrm{~s}$, water rinsed for $2 \mathrm{~s}$, stained with Gram's iodine for $1 \mathrm{~min}$, water rinsed, washed with 95\% ethanol for 10-30 s, stained with safranin for 30-60 s, water rinsed and finally dried (Prescott, 2002).

Flagella stain was also performed as described by BD Flagella Stain Droppers manufacturer's instructions (Difco, BBL).

Cytochrome $c$ oxidase and catalase tests were carry out: for the oxidase test - fresh growth from the culture plate was scraped with an inoculation loop, rubbed on filter paper and examined for blue color (positive result) within $10 \mathrm{~s}$ (NHS, Oxidase Test; Oxidase Test Sticks - Frilabo, Portugal); for the catalase test - a drop of 3\% hydrogen peroxide was placed on a glass slide and a colony from the culture plate was placed on the drop. The formation of bubbles indicated a positive result (Murray et al., 1998).

Starch hydrolysis was also studied according to manufacturer's instructions: the surface of a $48 \mathrm{~h}$ culture, grown in Difco Starch agar was flooded with Gram's Iodine; a positive result is indicated by the presence of a colorless zone surrounding the colonies.

The study of bacterial growth at $41^{\circ} \mathrm{C}$ was also performed.

All identification tests described above were performed five times to confirm results.

The bacterial species were finally subjected to the identification systems API20E (bioMérieux Company, Craponne, France). After obtaining the numerical profile, isolated bacterial colonies were analyzed using the analytical catalog of the API20E (API20E Analytical Catalog, 1999).

\subsection{Identification of bacteria by molecular methods}

Total genomic bacterial DNA was successfully extracted for all 38 bacterial colonies (except colony 10) according to Wiedmann-Al-Ahmad et al. (1994): one bacterial colony was resuspended in $70 \mu \mathrm{l}$ pure water, heated $5 \mathrm{~min}$ at $95^{\circ} \mathrm{C}$ and sedimented at $16,000 \mathrm{~g}$ for $5 \mathrm{~min}$ in a microcentrifuge (Thermo Scientific Heraeus Pico 17). The extracted DNA was quantified spectrophotometrically using a NanoPhotometer ${ }^{\mathrm{TM}}$ UV/Vis spectrophotometer (Implen GmbH, Germany). 16S rRNA genes were then PCR amplified: the mixture contained $25 \mathrm{mM} \mathrm{MgCl}$ (Fermentas, USA), $10 \times$ Taq Buffer with $\mathrm{KCl}(500 \mathrm{mM} \mathrm{KCl}$, $100 \mathrm{mM}$ Tris- $\mathrm{HCl}$ (pH 8.8), 0.8\% (v/v) Nonidet P40) (Fermentas, USA), $25 \mathrm{mM}$ of each primer 27F (5'-GAGTTTGATCCTGGCTCA-3') and 1492R (5'-TACCTTGTTACGACTT-3'), 500 U Taq DNA polymerase (Fermentas, USA) and $10 \mathrm{mM}$ dNTPs (Bioron, Frilabo, Portugal). The amplification was performed in a thermocycler DOPPIO (VWR, USA) with the following parameters: an initial denaturation step at $95^{\circ} \mathrm{C}$ for $5 \mathrm{~min}$, followed by 25 cycles at $95^{\circ} \mathrm{C}$ for $30 \mathrm{~s}, 54^{\circ} \mathrm{C}$ for $30 \mathrm{~s}$ and $72{ }^{\circ} \mathrm{C}$ for $1 \mathrm{~min}$ and a final extension at $72^{\circ} \mathrm{C}$ for $5 \mathrm{~min}$. The amplified products were analyzed by electrophoresis in a $1.5 \%$ agarose gel in Tris-acetate-EDTA (TAE) buffer, with SYBR Safe DNA gel stain (Invitrogen, UK) for $45 \mathrm{~min}$ at $120 \mathrm{~V}$.

PCR products from 34 of the total 38 bacterial colonies were sent for purification and sequencing by Macrogen Korea. The obtained sequences were finally subjected to a blastN.

\subsection{Nucleotide sequence accession numbers}

The 16S rRNA gene sequences of the bacterial colonies isolated reported in this study have been deposited in EMBL database under the accession numbers from FR821638 to FR821671.

\subsection{Statistical analysis}

Obtained data were analyzed using GraphPad InStat for Windows (Version 3.05, 16 bit, GraphPad Sotware, Inc.). Treatment differences were tested by one-way ANOVA - Tukey comparison $(p<0.05)$.

\section{Results and discussion}

\subsection{Stage symptoms and oleoresin flow}

After inoculation of pines with the four different nematode isolates, pines for each treatment were studied for the presence/ absence of oleoresin flow and the general appearance of the plant

Table 1

General appearance and oleoresin flow of inoculated plants at the three experimental time points.

\begin{tabular}{|c|c|c|c|c|}
\hline $\begin{array}{l}\text { Experimental } \\
\text { time point }\end{array}$ & Treatment & Symptom & $\begin{array}{l}\text { Oleoresin } \\
\text { flow }\end{array}$ & Stage \\
\hline \multirow[t]{5}{*}{ 3hai } & $\varnothing$ & None & Normal & 1 \\
\hline & $8 \mathrm{~A}$ & None & Normal & 1 \\
\hline & $\mathrm{HF}$ & None & Normal & 1 \\
\hline & 20 & None & Normal & 1 \\
\hline & C14-5 & None & Normal & 1 \\
\hline \multirow[t]{5}{*}{ 7dai } & $\varnothing$ & None & Normal & 1 \\
\hline & $8 \mathrm{~A}$ & None & Normal & 3 \\
\hline & $\mathrm{HF}$ & Discoloration of old needles & Decreasing & 3 \\
\hline & 20 & Discoloration of old needles & Decreasing & 3 \\
\hline & C14-5 & Discoloration of old needles & Decreasing & 3 \\
\hline \multirow[t]{5}{*}{ 14dai } & $\varnothing$ & None & Normal & 1 \\
\hline & $8 \mathrm{~A}$ & $\begin{array}{l}\text { Discoloration of young } \\
\text { needles }\end{array}$ & None & 4 \\
\hline & $\mathrm{HF}$ & $\begin{array}{l}\text { Discoloration of young } \\
\text { needles }\end{array}$ & None & 4 \\
\hline & 20 & $\begin{array}{l}\text { Discoloration of young } \\
\text { needles }\end{array}$ & None & 4 \\
\hline & C14-5 & Discoloration of old needles & Decreasing & 3 \\
\hline
\end{tabular}


was also registered according to Zhao et al. (2008). The results are shown in Table 1.

The progression of symptoms was as expected - healthy pines in the early infection (3hai) and severely diseased pines at 14dai. It was observed that pines inoculated with the avirulent isolate C14-5 led to a slower aggravation of symptoms, consistent with what was observed in other experiments (Kosaka et al., 2001).

\subsection{Determination of the presence/absence of nematodes at different stages of disease progression}

In order to verify the effectiveness of the inoculation process, five pines for each treatment were chosen to check whether the nematodes were present in the inoculated trees. The results of the extraction process showed that the nematodes had survived in the inoculated pines for all treatments, 3hai and 7dai. At 14dai, nematodes were recovered from pines inoculated with nematode isolates 20 and HF but were not recovered from those inoculated with nematodes $8 \mathrm{~A}$ and $\mathrm{C} 14-5$. This indicates that either the extraction process was not efficient or nematodes may have migrated to other plant parts (needles or roots, for example). In addition, no nematodes were detected in the control pines, as expected, which was also observed in the experiments of Han et al. (2003) and Xie and Zhao (2008).

\subsection{Quantification of bacterial colonies on inoculated chips}

In Tables 2-4 the average number of chips with bacterial colonies and the standard deviation for the various treatments in the different experimental time points are visible.

Three hours after inoculation, the quantity of chips with bacteria between treatments was not significantly different and was generally low compared to disease progression (7dai and 14dai); as in the experiment of Han et al. (2003), Zhao et al. (2003) and Xie and Zhao (2008) no bacteria were found in the control (Table 2 ). The highest quantity of chips with bacterial colonies was found in 8A and C14-5 nematode isolates (Table 2).

Seven days after inoculation, the amount of bacteria between treatments was significantly different. In general, bacterial quantity increased, compared to 3hai experiment, with exception of isolate $8 \mathrm{~A}$, which remained the same (Table 3 ). This increase indicates that the presence of the nematode, in some way, raises the bacterial population inside the tree (Jones et al., 2008; Xie and Zhao, 2008). This could result from the supply of food or essential nutrients, by the nematodes, which leads to bacterial multiplication (Zhao and Lin, 2005; Zhao et al., 2007; Wang et al., 2010). At this experimental point, and contrary to what Han et al. (2003), Zhao et al. (2003) and Xie and Zhao (2008) reported for their experiments, bacteria were found in the control pines but the amount was clearly lower than that obtained in the treatments inoculated with the different nematodes (Table 3 ). These bacteria may be natural contaminants from the soil or the plant. In fact bacteria have been isolated from buds of healthy Scotch pines (Pinus sylvestris L.) (Pirtillä et al., 2000); they can also be associated with some plant diseases as the bacterial wetwood disease (Anonymous, 1999). Seven days after inoculation, it was found that the virulent isolates $\mathrm{HF}$ and 20 led to a greater amount of bacteria, compared to $8 \mathrm{~A}$ and the avirulent isolate $\mathrm{C} 14-5$.

Fourteen days after inoculation (Table 4), the amount of bacteria in the chips between treatments was significantly different. Again, bacteria were found in the control pines and generally in a lower amount than that obtained with nematode inoculations. The presence of nematodes stimulated, once again, bacterial growth. For the isolate C14-5 few bacteria were found in the chips at 14dai, compared to those from the 7dai experiment, which indicates that either nematodes did not survive, or because it is an avirulent isolate, the symbiotic relationship with bacteria is lower or nonexistent compared to that seen with the virulent isolates.

Over the three experimental time points, the bacterial quantity for the isolate HF always increased, suggesting that this is probably the most virulent isolate.

\subsection{Identification of bacteria by classical methods and API20E system}

As an initial exploratory approach, the identification of bacteria was performed using classical methods. In total, 38 bacterial colonies were isolated and identified from inoculated chips and

Table 2

Number of inoculated chips with bacterial colonies, 3hai.

\begin{tabular}{|c|c|c|c|c|c|}
\hline \multirow{2}{*}{$\begin{array}{l}\text { Experimental point } \\
\text { Treatments }\end{array}$} & \multicolumn{5}{|l|}{ 3hai } \\
\hline & $\emptyset$ & C14-5 & $\mathrm{HF}$ & 20 & $8 \mathrm{~A}$ \\
\hline \# Of chips with bacterial colonies mean \pm SD (total \# of samples) & $0(8)$ & $1 \pm 0.4(8)$ & $0.2 \pm 0.7(8)$ & $0.2 \pm 0.4(8)$ & $1.4 \pm 1.5(8)$ \\
\hline
\end{tabular}

Table 3

Number of inoculated chips with bacterial colonies, 7dai.

\begin{tabular}{|c|c|c|c|c|c|}
\hline \multirow{2}{*}{$\begin{array}{l}\text { Experimental point } \\
\text { Treatments }\end{array}$} & \multicolumn{5}{|l|}{ 7dai } \\
\hline & $\varnothing$ & C14-5 & $\mathrm{HF}$ & 20 & $8 \mathrm{~A}$ \\
\hline $\begin{array}{l}\text { \# Of chips with bacterial colonies mean } \pm \text { SD (total \# of } \\
\text { samples) }\end{array}$ & $\begin{array}{l}0.6^{\mathrm{C}, \mathrm{D}} \pm 0.5 \\
(8)\end{array}$ & $\begin{array}{l}2^{\mathrm{C}, \mathrm{D}} \pm 1.6 \\
(8)\end{array}$ & $\begin{array}{l}5.4^{\mathrm{A}, \mathrm{B}, \mathrm{E}} \pm 2.2 \\
(8)\end{array}$ & $\begin{array}{l}4.8^{\mathrm{A}, \mathrm{B}, \mathrm{E}} \pm 1.3 \\
(8)\end{array}$ & $1.4^{\mathrm{C}, \mathrm{D}} \pm 0.5(8)$ \\
\hline
\end{tabular}

Means marked with different letters are significantly different ( $p<0.05$; Tukey): ${ }^{A}$ from control $(\emptyset)$; ${ }^{B}$ from isolate $\mathrm{C} 14-5 ;{ }^{C}$ from isolate HF; ${ }^{D}$ from isolate 20; ${ }^{\mathrm{E}}$ from isolate $8 \mathrm{~A}$.

Table 4

Number of inoculated chips with bacterial colonies, 14dai.

\begin{tabular}{|c|c|c|c|c|c|}
\hline \multirow{2}{*}{$\begin{array}{l}\text { Experimental point } \\
\text { Treatments }\end{array}$} & \multicolumn{5}{|l|}{ 14dai } \\
\hline & $\varnothing$ & C14-5 & $\mathrm{HF}$ & 20 & $8 \mathrm{~A}$ \\
\hline $\begin{array}{l}\text { \# Of chips with bacterial colonies mean } \pm \text { SD (total \# of } \\
\text { samples) }\end{array}$ & $\begin{array}{l}0.6^{\mathrm{C}} \pm 0.5 \\
(8)\end{array}$ & $\begin{array}{l}1^{\mathrm{C}} \pm 0.7 \\
(8)\end{array}$ & $\begin{array}{l}5.8^{\mathrm{A}, \mathrm{B}, \mathrm{D}, \mathrm{E}} \pm 1.1 \\
(8)\end{array}$ & $\begin{array}{l}0.4^{\mathrm{C}} \pm 0.5 \\
(8)\end{array}$ & $\begin{array}{l}2.4^{\mathrm{C}} \pm 2.6 \\
(8)\end{array}$ \\
\hline
\end{tabular}

Means marked with different letters are significantly different $\left(p<0.05\right.$; Tukey): ${ }^{A}$ from control $(\varnothing) ;{ }^{B}$ from isolate C14-5; ${ }^{C}$ from isolate HF; ${ }^{D}$ from isolate 20 ; ${ }^{\mathrm{E}}$ from isolate $8 \mathrm{~A}$. 
from individual nematodes by classical methods and the API20E system.

First, two bacterial colonies were isolated from the surface of each nematode isolate. The bacterial colonies had no variation in their morphology (rod-shaped bacteria were seen). All of them were gram-negative, positive for the catalase test and negative for the oxidase test. No colonies were able to hydrolyze starch and all of them, with exception of one isolated from $8 \mathrm{~A}$ isolate, grew at $41^{\circ} \mathrm{C}$. The presence of flagella was verified in one of the colonies isolated from isolate $\mathrm{C} 14-5$, the two colonies isolated from isolate $\mathrm{HF}$, one isolated from isolate 20 and one from isolate $8 \mathrm{~A}$.

Ten individualized colonies from each nematode isolate were recovered from the inoculated pines, at each experimental time point (3hai, 7dai and 14dai). All the 30 bacterial colonies were rod-shaped, as in the experiments of Han et al. (2003) and Xie and Zhao (2008). One bacterial colony was isolated from control pines ( $\varnothing$ - non-treatment) at each experimental point of 7dai and 14dai; no bacterial colonies were isolated from controls at 3 hai. From the three experimental time points, $70 \%$ were grampositive, all were positive for the catalase test (93\% of Xie and Zhao (2008) isolates were catalase positive), $73 \%$ were oxidase negative, $33 \%$ did not hydrolyze starch, $87 \%$ grew at $41{ }^{\circ} \mathrm{C}$ and $63 \%$ showed flagella when viewed by the flagella staining. In the experiment of Zhao et al. (2003), 79\% of their isolates were oxidase negative (similar to our results) and $92 \%$ were gram-negative.

The API20E identification system was performed to help in the identification of the bacterial species. After analysis of the numerical profile obtained, the main group of bacteria found belonged to the species Enterobacter cloacae (30 of the 38 isolated bacterial colonies). This species was also isolated in the work of Xie and Zhao (2008). The bacterial species isolated from control pines 7dai and identified as E. cloacae, may be involved in the bacterial wetwood disease, as mentioned above, as it is a species reported to be related to it (Anonymous, 1999). One of the bacterial colonies isolated from the surface of the nematode C14-5 was identified as Citrobacter freundii. To the best of our knowledge, this has never been shown before for bacteria associated with B. xylophilus. As the API20E system only identifies gram-negative bacterial species, and we have isolated seven gram-positive bacteria, these last ones could not be identified by this method; so, it became necessary to find another identification method for the latter ones. Therefore, DNA sequencing methods were also used to help in the identification process. This method proved effective for Kwon et al. (2010) and Proença et al. (2010).

\subsection{Identification of bacteria by molecular methods}

Total genomic bacterial DNA was extracted from all isolated colonies (except from bacterial colony 10 that failed to grow on NA medium) and an $1500 \mathrm{bp}$ fragment of $16 \mathrm{~S}$ rRNA gene was PCR amplified with bacterial universal primers. A total of 34 PCR products were purified and sequenced by Macrogen Ltd. (Seoul, Korea) (bacterial colonies 19, 21 and 24, were not sequenced because the obtained DNA concentration was too low). The obtained sequences were finally subjected to a blastN and the results of the bacterial species obtained are shown in Table 5 .

In this experiment, of the 34 isolated bacterial colonies, 11 different species were identified. The main bacterial species found were Klebsiella oxytoca (52.9\% of the total), Bacillus spp. (17.6\% of the total) and Enterobacter spp. (11.8\% of the total).

The predominant species found 3hai was Bacillus spp. Kawazu and Kaneko (1997) and Kawazu (1998) also isolated three bacteria of the genus Bacillus (B. cereus, B. subtilis and B. megaterium); these constitute a diverse group of bacteria, widely distributed in soil and aquatic environments (Parvathi et al., 2009). B. pumilus is
Table 5

Bacterial species isolated from trees inoculated with the four nematode isolates in the three experimental time points and bacteria isolated from non-inoculated nematodes.

\begin{tabular}{|c|c|c|c|}
\hline Sample & Treatment & $\begin{array}{l}\text { Experimental time } \\
\text { point }\end{array}$ & $\begin{array}{l}\text { Associated bacterial } \\
\text { species }^{\text {a }}\end{array}$ \\
\hline 22 & \multirow[t]{4}{*}{$8 \mathrm{~A}$} & \multirow[t]{4}{*}{ 3hai } & Bacillus megaterium \\
\hline 23 & & & Bacillus pumilus \\
\hline 25 & & & Bacillus megaterium \\
\hline 26 & & & Klebsiella oxytoca \\
\hline 4 & $8 \mathrm{~A}$ & 7dai & Klebsiella oxytoca \\
\hline 18 & \multirow[t]{2}{*}{$8 \mathrm{~A}$} & \multirow[t]{2}{*}{ 14dai } & Klebsiella oxytoca \\
\hline 20 & & & Paenibacillus tundrae \\
\hline 37 & \multirow[t]{2}{*}{$8 \mathrm{~A}$} & \multirow[t]{2}{*}{ IN } & Klebsiella oxytoca \\
\hline 38 & & & Klebsiella oxytoca \\
\hline 30 & $\mathrm{HF}$ & 3hai & Enterobacter cloacae \\
\hline 7 & \multirow[t]{3}{*}{$\mathrm{HF}$} & \multirow[t]{3}{*}{ 7dai } & Enterobacter cloacae \\
\hline 8 & & & Klebsiella oxytoca \\
\hline 9 & & & Klebsiella oxytoca \\
\hline 11 & \multirow[t]{3}{*}{$\mathrm{HF}$} & \multirow[t]{3}{*}{ 14dai } & Terribacillus shanxiensis \\
\hline 12 & & & Klebsiella oxytoca \\
\hline 13 & & & Enterobacter oryzae \\
\hline 33 & \multirow[t]{2}{*}{$\mathrm{HF}$} & \multirow[t]{2}{*}{ IN } & Citrobacter freundii \\
\hline 34 & & & Klebsiella oxytoca \\
\hline 27 & 20 & 3hai & Bacillus simplex \\
\hline 1 & \multirow[t]{3}{*}{20} & \multirow[t]{3}{*}{ 7dai } & Klebsiella oxytoca \\
\hline 2 & & & Klebsiella oxytoca \\
\hline 3 & & & Enterobacter cloacae \\
\hline 16 & \multirow[t]{2}{*}{20} & \multirow[t]{2}{*}{ 14dai } & Klebsiella oxytoca \\
\hline 17 & & & Pantoea agglomerans \\
\hline 35 & \multirow[t]{2}{*}{20} & \multirow[t]{2}{*}{ IN } & Klebsiella oxytoca \\
\hline 36 & & & Escherichia coli \\
\hline 28 & \multirow[t]{2}{*}{ C14-5 } & \multirow[t]{2}{*}{ 3hai } & Bacillus megaterium \\
\hline 29 & & & Klebsiella oxytoca \\
\hline 5 & \multirow[t]{2}{*}{ C14-5 } & \multirow[t]{2}{*}{ 7dai } & Citrobacter freundii \\
\hline 6 & & & Klebsiella oxytoca \\
\hline 14 & C14-5 & 14dai & Klebsiella oxytoca \\
\hline 31 & \multirow[t]{2}{*}{ C14-5 } & \multirow[t]{2}{*}{ IN } & Klebsiella oxytoca \\
\hline 32 & & & Klebsiella oxytoca \\
\hline 15 & $\emptyset$ & 14dai & Bacillus megaterium \\
\hline
\end{tabular}

a Bacteria were identified after blastN of the amplified 16S rRNA gene fragment; IN, isolated from the surface of nematodes.

highly resistant to extreme environmental conditions (Nicholson et al., 2000) and produces compounds antagonist to fungal and bacterial pathogens (Aunpad and Na-Bangchang, 2007; Banerjee et al., 2007). B. megaterium has shown to have a toxic effect in vitro against B. xylophilus (Hwang et al., 2001; Siddiqui and Shaukat, 2005) being found in diverse environments from soils to seawater (Vary, 1994). Its nematode suppression capacity has been shown in the studies of Biedendieck (2007) and Huang et al. (2010).

Seven days after inoculation, the predominant species found was Klebsiella oxytoca, isolated from all nematode isolates. From the avirulent isolate, a unique species was identified: Citrobacter freundii. This species has been described as a possible control agent for the nematode Meloidogyne javanica, being found in water, sewage, soil and food (Fabry et al., 2007).

Fourteen days after inoculation, the bacterial colony diversity significantly increased, as expected and according to what Xie and Zhao (2008) obtained in their work (Fig. 1). Also in the present work, population and bacterial species number increased as the disease progressed. As in the previous experimental time point, $K$. oxytoca was the predominant species found, indicating that this species is a potential bacteria related to the disease and probably the one truly involved in it, in this geographic zone. $K$. oxytoca species make part of an endophytic population of bacteria that play an important role in plant growth and development (Hallmann et al., 1997); this nitrogen-fixing bacterium has been isolated from 

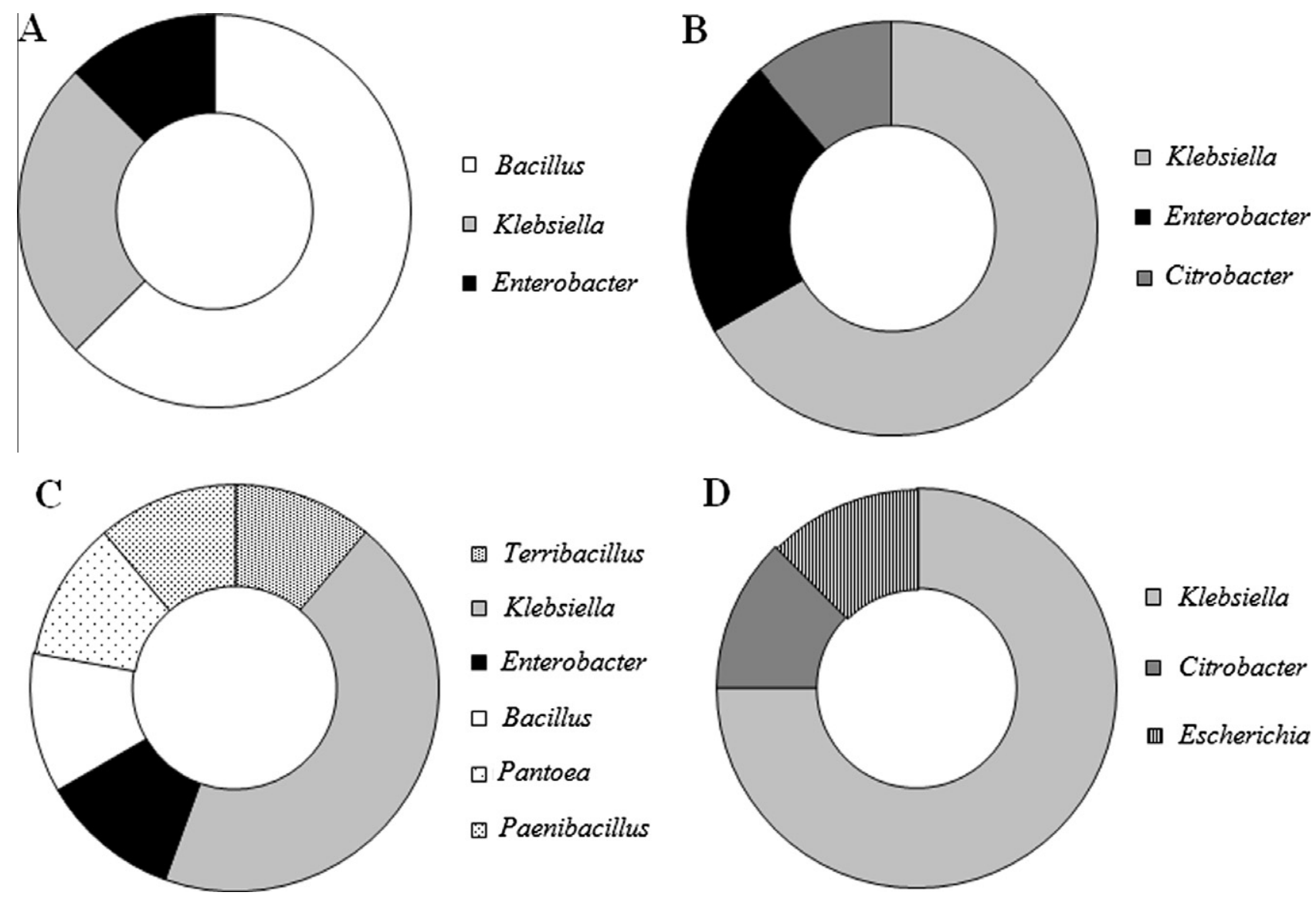

Bacillus

\section{Klebsiella}

Enterobacter

Terribacillus

D

Klebsiella

Enterobacter

Bacillus

$\square$ Pantoea

망 Paenibacillus

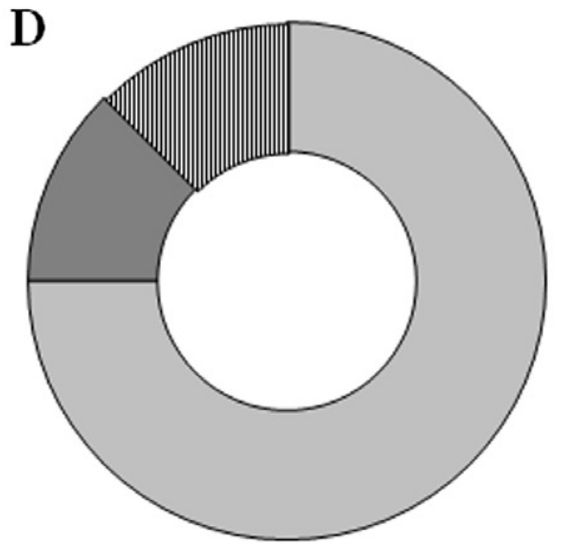

\section{Klebsiella}

Citrobacter

Escherichia

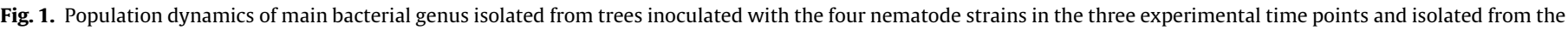
surface of nematodes. (A) 3hai. (B) 7dai. (C) 14dai. (D) Bacteria isolated directly from the nematodes.

rice roots (Nguyen et al., 1989), and is associated with bacterial wetwood of elms (Anonymous, 1999).

Bacterial colonies were also isolated from the surface of the four nematodes isolates. $K$. oxytoca was isolated from all nematode isolates, indicating that this species is associated with the nematode and establishes a symbiosis with it. No previous work had identified $K$. oxytoca, suggesting again that this species is specific to this geographic area. A C. freundii species, also found in trees inoculated with isolate $\mathrm{C} 14-5$, was also recovered from isolate HF. A species of Escherichia coli was isolated from isolate 20, not being isolated from any tree inoculated with the four nematode isolates. This species has already been found in previous work, being isolated from wild PWN (Zhao et al., 2003), from P. massoniana naturally infected with B. xylophilus (Zhao and Lin, 2005) and from inoculated black pine (Pinus thunbergii) with B. xylophilus (Xie and Zhao, 2008). Zhao and Lin (2005) reported that this species inhibited PWN reproduction. As described for C. freundii, E. coli also proved to be efficient for the control of the nematode Meloidogyne javanica, reducing number of galls in 80\% (Fabry et al., 2007). Species diversity from nematodes was not very large compared to those isolated from trees, which indicates that nematodes, apart from owning bacteria in their body, establish symbiotic relationships with bacteria from inside the tree during the infection process, and so all these dynamics can contribute to symptom disease development.

In the current work, at any experimental time point and with any treatment, Pseudomonas spp. species was not found. This is an interesting finding, since this species was isolated in several previous works (Han et al., 2003; Zhao et al., 2003; Zhao and Lin, 2005; Xie and Zhao, 2008) which supports the fact that bacteria differ between geographic zones (Han et al., 2003; Wang et al.,
2010); in fact when PWN occupies a new region, new bacteria are taken from the local flora (Zhao, 2008). In China the dominant bacterial species belong to the genus Pseudomonas (Zhao et al., 2003; Tan and Feng, 2004), in Japan Bacillus spp. are dominant (Kawazu et al., 1996a,b) and in Korea both genera exists (Zhao, 2008). P. tundrae, T. shanxiensis and $C$. freundii have never been isolated in any previous experiment, suggesting that along with $K$. oxytoca, these may be specific to the Portuguese geographic zone, as the plant material originated from Anadia, Portugal, and the bacteria were isolated from Setúbal region and Po rtuguese central region. Furthermore, this is the first report on the bacterial population of an avirulent nematode isolate and contrary to previous studies, the experiments were carried out on $P$. pinaster and not in $P$. thunbergii, $P$. densiflora, or P. massoniana.

\section{Acknowledgments}

This work was supported by National Forest Authority, Agriculture Ministry, and Rural and Fisheries Development. The authors are extremely grateful to Dr. Hajime Kosaka and Dr. Mitsuteru Akiba for providing the avirulent nematode strain, C14-5, and to Dr. Manuel Mota for providing the virulent strains.

\section{References}

Aikawa, T., 2008. Transmission biology of Bursaphelenchus xylophilus in relation to its insect vector. In: Zhao, B.G., Futai, K., Sutherland, J.R., Takeuchi, Y. (Eds.), Pine Wilt Disease. Springer, Japan, pp. 123-138.

Anonymous, 1999. Bacterial Wetwood and Slime Flux of Landscape Trees. University of Illinois Extension, p. 5.

API20E Analytical Catalog, 1999. Biomérieux, 5th ed. 
Aunpad, R., Na-Bangchang, K., 2007. Pumilicin 4, a novel bacteriocin with antiMRSA and anti-VRE activity produced by newly isolated bacteria Bacillus pumilus strain WAPB4. Current Microbiology 55, 308-313.

Banerjee, S., Devaraja, T.N., Shariff, M., Yusoff, F.M., 2007. Comparison of four antibiotics with indigenous marine Bacillus spp. in controlling pathogenic bacteria from shrimp and artemia. Journal of Fish Diseases 30, 383-389.

Biedendieck, R.K.J., 2007. Bacillus megaterium: Versatile Tools for Production, Secretion and Purification of Recombinant Proteins [Ph.D. dissertation]. Braunschweig University of Technology, Berlin, 169pp.

Cao, Y., 1997. Studies on toxin of pine wilt disease caused by pine wood nematode [Ph. D. dissertation]. Nanjing Forestry University, 46pp.

Fabry, C.F.S., Freitas, L.G., Neves, W.S., Coutinho, M.M., Tótola, M.R., Oliveira, J.R., Dallemole-Giaretta, R., Ferraz, S., 2007. Obtenção de Bactérias para Biocontrole de Meloidogyne javanica por Meio de Aquecimento de Solo e Tratamento com Filtrado de Raízes de Plantas Antagonistas a Fitonematóides. Fitopatologia Brasileira 32, 079-082.

Fukuda, K., Hogetsu, T., Suzuki, K., 1992. Cavitation and cytological changes in xylem of pine seedlings inoculated with virulent and avirulent isolates of Bursaphelenchus xylophilus and B. mucronatus. Journal of the Japanese Forest Society 74, 289-298.

Futai, K., 1980. Population dynamics of Bursaphelenchus lignicolus (Nematoda: Aphelenchoididae) and B. mucronatus in pine seedlings. Applied Entomology and Zoology 15, 458-464.

Hallmann, J., Quadt-Hallmann, A., Mahaffee, W.F., Kloepper, J.W., 1997. Bacteria endophytes in agricultural crops. Canadian Journal of Microbiology 43, 895-914.

Han, Z.M., Hong, Y.D., Zhao, B.G., 2003. A study on pathogenicity of bacteria carried by pine wood nematodes. Journal of Phytopathology 151, 683-689.

Higgins, D.F., Harmy, M.A., Jones, D.L., 1999. Pathogenicity related gene expression in Bursaphelenchus xylophilus. In: Sustainability of Pine Forests in Relation to Pine Wilt and Decline, Tokyo, Japan. Proceedings of International Symposium, 27-28 October 1998. Kyoto, Japan, pp. 23-28.

Huang, Y., Xu, C., Ma, L., Zhang, K., Duan, C., Mo, M., 2010. Characterization of volatiles produced from Bacillus megaterium YFM3.25 and their nematicida activity against Meloidogyne incognita. European Journal of Plant Pathology 126 417-422.

Hwang, B.K., Lim, S.W., Kim, B.S., Lee, J.Y., Moon, S.S., 2001. Isolation and in vivo and in vitro antifungal activity of phenylacetic acid and sodium phenylacetate from Streptomyces humidus. Applied and Environmental Microbiology 67, 37393745.

Jones, J.T., Moens, M., Mota, M., Li, H., Kikuchi, T., 2008. Bursaphelenchus xylophilus: opportunities in comparative genomics and molecular host-parasite interaction. Molecular Plant Pathology 9, 357-368.

Kawazu, K., Zhang, H., Kanazaki, H., 1996a. Accumulation of benzoic acid in suspension cultured cells of Pinus thunbergii Parl in response to phenyl acetic acid administration. Bioscience, Biotechnology and Biochemistry 60, 14101412.

Kawazu, K., Zhang, H., Yamashita, H., Kanzaki, H., 1996b. Relationship between the pathogenicity of the pine wood nematode, Bursaphelenchus xylophilus, and phenyl acetic acid production. Bioscience, Biotechnology and Biochemistry 60 1413-1415.

Kawazu, K., Kaneko, N., 1997. Asepsis of the pine wood nematode isolate OKD-3 causes it to lose its pathogenicity. Japanese Journal of Nematology 27, 76-80.

Kawazu, K., 1998. Pathogenic toxins of pine wilt disease. Kagaku to Seibutsu 36, $120-124$

Kosaka, H., Aikawa, T., Ogura, N., Tabata, K., Kiyohara, T., 2001. Pine Wilt Disease caused by the pine wood nematode: the induced resistance of pine trees by the avirulent isolates of nematode. European Journal of Plant Pathology 107 667-675

Kwon, H.R., Choi, G.J., Choi, Y.H., Jang, K.S., Sung, N., Kang, M.S., Moon, Y., Lee, S.K., Kim, J., 2010. Supression of pine wilt disease by an antibacterial agent, oxolinic acid. Pest Management Science 66, 634-639.

Mamiya, Y., 1983. Pathology of the pine wilt disease caused by Bursaphelenchus xylophilus. Annual Review of Phytopathology 21, 201-220.

Mota, M.M., Vieira, P.C., 2008a. Pine wilt disease in portugal. In: Zhao, B.G., Futai, K. Sutherland, J.R., Takeuchi, Y. (Eds.), Pine Wilt Disease. Springer, Japan, pp. 33-38.

Mota, M.M., Vieira, P., 2008b. Pine Wilt Disease: A Worldwide Threat to Forest Ecosystems. Springer, Netherlands.

Murray, P.R., Rosenthal, K.S., Kobayashi, G., Pfaller, M.A., 1998. Medica microbiology, 3rd ed. Mosby Elsevier Health Science, St. Louis.

Myers, R.F., 1988. Pathogenesis in pine wilt caused by pine wood nematode Bursaphelenchus xylophilus. Journal of Nematology 20, 236-244.

Nguyen, T., Ton, T., Tarasenko, V., Kozyrovska, N., 1989. Nitrogen-fixing bacteria colonize the rice root xylem. Biopolymery i Klityna 5, 97-99.

Nicholson, W.L., Munakata, N., Horneck, G., Melosh, H.J., Setlow, P., 2000. Resistance of Bacillus endospores to extreme terrestrial and extraterrestrial environments. Microbiology and Molecular Biology Reviews 64, 548-572.

Nickle, W.R., Golden, A.M., Mamiya, Y., Wergin, W.P., 1981. On the taxonomy and morphology of the pine wood nematode, Bursaphelenchus xylophilus (Steiner \& Buhrer, 1934) Nickle 1970. Journal of Nematology 13, 385-392.

Nobuchi, T., Tominaga, T., Futai, K., Harada, H., 1984. Cytological study of pathological changes in Japanese black pine (Pinus thunbergii) seedlings after inoculation with pinewood nematode (Bursaphelenchus xylophilus). Bull Kyoto University Forests 56, 224-233.

Oku, H., Shiraishi, T., Kurozumi, S., 1979. Participation of Toxin in Wilting of Japanese Pines Caused by a Nematode. Naturwissenschaften 66, 210-211.
Oku, H., Shiraishi, T., Ouchi, S., Kurozumi, S., Ohta, H., 1980. Pine wilt toxin, the metabolite of a bacterium associated with a nematode. Naturwissenschaften 67, 198-199.

Parvathi, A., Krishna, K., Jose, J., Joseph, N., Nair, S., 2009. Biochemical and molecular characterization of Bacillus pumilus isolated from coastal environment in Cochin, India. Brazilian Journal of Microbiology 40, 269-275.

Pirtillä, A.M., Laukkanen, H., Pospiech, H., Myllyla, R., Hohtola, A., 2000. Detection of intracellular bacteria in the buds of scotch pine (Pinus sylvestris L.) by in situ hybridization. Applied and Environmental Microbiology 66, 30733077 .

Prescott, L.M., 2002. Microbiology, 5th ed. McGraw-Hill, Columbus, p. 1026.

Proença, D.N., Francisco, R., Santos, C.V., Lopes, A., Fonseca, L., Abrantes, I.M.O., Morais, P.V., 2010. Diversity of bacteria associated with Bursaphelenchus xylophilus and other nematodes isolated from Pinus pinaster trees with pine wilt disease. PLoS ONE 5, 1-9.

Siddiqui, I.A., Shaukat, S.S., 2005. Phenylacetic acid-producing Rhizoctonia solani represses the biosynthesis of nematicidal compounds in vitro and influences biocontrol of Meloidogyne incognita in tomato by Pseudomonas fluorescens strain CHAO and its GM derivates. Journal of Applied Microbiology 98, 43-55.

Sousa, E., Bravo, M.A., Pires, J., Naves, P.M., Penas, A.C., Bonifácio, L., Mota, M., 2001. Bursaphelenchus xylophilus (Nematoda: Aphelenchoididae) associated with Monochamus galloprovincialis (Coleoptera: Cerambycidae) in Portugal. Nematology 3, 89-91.

Sousa, E., Naves, P., Bonifácio, L., Bravo, M.A., Penas, A.C., Pires, J., Serrão, M., 2002. Preliminary survey for insects associated with Bursaphelenchus xylophilus in Portugal. Bull OEPP/EPPO Bull 32, 499-502.

Tamura, H., 1983. Pathogenicity of aseptic Bursaphelenchus xylophilus and associated bacteria to pine seedlings. Japanese Journal of Nematology 13, 1-5.

Tan, J.J., Feng, Z.X., 2004. Population dynamics of pine wood nematode and its accompanying bacterium in the host. Scientia Silvae Sinicae 40, 110-114.

van Bezooijen, J., 2006. Methods and Techniques for Nematology. Available from: <http://www.nem.wur.nl/NR/rdonlyres/CCOA519F-3ADD-4FFA-B473959062BC9C7F/47007/MethodsandTechniquesforNematology1.pdf $>$ [date visited: $4 / 3 / 09]$.

Vary, P.S., 1994. Prime time for Bacillus megaterium. Microbiology 140, 1001-1013.

Wang, Z., Wang, C.Y., Fang, Z.M., Zhang, D.L., Liu, L., Lee, M.R., Li, Z., Li, J.L., Sung, C.K., 2010. Advances in research of pathogenic mechanism of pine wilt disease. African Journal of Microbiology Research 4, 437-442.

Wiedmann-Al-Ahmad, M., Tichy, H.-V., Schön, G., 1994. Characterization of Acinetobacter type strains and isolates obtained from wastewater treatment plants by PCR fingerprinting. Applied and Environmental Microbiology 60, 4066-4071.

Xie, L.Q., Zhao, B.G., 2008. Post-inoculation population dynamics of Bursaphelenchus xylophilus and associated bacteria in pine wilt disease on Pinus thunbergii. Journal of Phytopathology 156, 385-389.

Yang, B.J., 2002. Advance in research of pathogenetic mechanism of pine wood nematode. Forest Pest and Disease 1, 27-31.

Yoshimura, A., Kawasaki, K., Takasu, F., Togashi, K., Futai, K., Shigesada, N., 1999. Modeling the spread of pine wilt disease caused by nematodes with pine sawyers as vector. Ecology 80, 1691-1702.

Zhao, B.G., Gao, R., Ju, Y.W., Guo, D.S., Guo, J., 2000. Effects of antibiotics on pine wilt disease. Journal of Nanjing Forestry University 24, 75-77.

Zhao, B.G., Wang, H.L., Han, S.F., Han, Z.M., 2003. Distribution and pathogenicity of bacteria species carried by Bursaphelenchus xylophilus in China. Nematology 5, 899-906.

Zhao, B.G., Liang, B., Zhao, L.G., Xu, M., 2005. Inference of pine wood nematode on production of phytotoxins of an accompanying pathogenic bacterial strain. Journal of Beijing Forestry University 27, 71-75.

Zhao, B.G., Lin, F., 2005. Mutualistic symbiosis between Bursaphelenchus xylophilus and bactéria of the genus Pseudomonas. Forest Pathology 35, 339-345.

Zhao, B.G., Liu, Y., Lin, F., 2007. Effects of bacteria associated with pine wood nematode (Bursaphelenchus xylophilus) on development and egg production of the nematode. Journal of Phytopathology 155, 26-30

Zhao, B.G., 2008. Bacteria carried by the pine wood nematode and their symbiotic relationship with the nematode. In: Zhao, B.G., Futai, K., Sutherland, J.R. Takeuchi, Y. (Eds.), Pine Wilt Disease. Springer, Japan, pp. 264-273.

Zhao, B.G., Futai, K., Sutherland, J.R., Takeuchi, Y., 2008. Pine Wilt Disease. Springer, Japan.

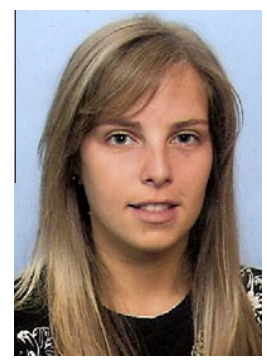

Mariana Roriz Lemos Costa was born on May 23, 1987. In 2008, she graduated from Escola Superior de Biotecnologia of Universidade Católica Portuguesa in Biosciences Degree (Microbiology). She is currently waiting to defend her Master's Degree thesis in Microbiology, that involved the study of population dynamics of bacteria associated with pine wood nematode after inoculation with different strains of Bursaphelenchus xylophilus in Pinus pinaster. In the future she would like to continue working in this area because of its scientific value and because it's a way to aid the Portuguese forest. 


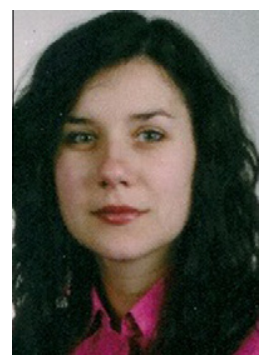

Carla Sofia Sancho dos Santos - born in Porto, Portugal, in 1987 - has graduated in Microbiology (2008) and now is ending a Master of Science degree in the same field at Universidade Católica Portuguesa. Her aim is to focus her early career in molecular biology and use it in more specific subjects, like the study of bacteria and plants, to have a wide range of knowledge. Currently is studying Bursaphelenchus xylophilus and it's interaction with maritime and stone pine trees.



Marta Wilton Pereira Leite de Vasconcelos - born in Lisbon, 1976 - graduated in Applied Plant Biology from Faculdade de Ciências da Universidade de Lisboa, completed her Ph.D. (2003) in the area of plant Biotechnology at the International Rice Research Institute, Philippines, was a Postdoctoral associate and Research Associate, for 5 years at the USDA/ARS lab at Baylor College of Medicine, USA, and since May of 2008 is the Head of the Plantech Laboratory at Escola Superior de Biotecnologia, Universidade Católica Portuguesa. 